\title{
Security spot monochromatic twin dyes of infrared cartography
}

\author{
Maja Matas \\ University of Zagreb, Faculty of Graphic Arts, Zagreb, Croatia \\ Corresponding author: Maja Matas, majamatasid@gmail.com
}

\begin{abstract}
The paper defines new color tones of dye pairs with identical L*a* $\mathrm{a}^{*} \mathrm{~b}^{*}$ (lightness color- opponent dimensions / brightness, chromaticity coordinates) values, but different responses in the infrared spectrum. Simulated through CMYK (cyan, magenta, yellow, key), spot dye tones are mixed by hand and defined for printing of large editions. The results visible with the ZRGB camera are prints of monochrome dyes with more or less Z (infrared) response. The absorption of infrared light in the $\mathrm{Z}$ dye twin pairs is reflected in the monochromatic light and darker color gray tones. Determined are desired levels of the visibility of the $\mathrm{Z}$ security infrared twin pair, shown in a range of grey tones. Set are new recipes for development of multilayered offset twin dyes for design beyond the visible spectrum. The research in an extension of the infrared security print method.
\end{abstract}

Keywords: spot colorants, cartographic offset print, security print, colorant twins, monochromatic tones

\section{Introduction}

Design of security graphics is widely used for documents with the goal of stop the possibility of falsification. The method IRD (INFRAREDESIGN $^{\circledR}$ ) [1] has been introduced as a new design solution for protective print. IRD algorithm is based on the given color setting and dependant on the CMYKIR (cyan magenta yellow key color infrared) separation [2], [3]. In the separation, the value of the $\mathrm{K}$ channel is set for the desired value before the separation for a precise setting of the hidden graphics. Produced are reproductions for the defined paper CMYK dyes combination for standard print technology [4]. Introduced as a concept in 2013., dye pairs with the same $\mathrm{L}^{*} \mathrm{a}^{*} \mathrm{~b}^{*}$ (lightness color-opponent dimensions / brightness, chromaticity coordinates) value but different light absorption properties in the near infrared spectrum [5] are named twin dyes [6]. For the implementation of IRD security in print, each color tone needs to have two dyes mixed from different recipes but with the same experience of color tone, with a difference not visible to the naked eye. The application of such dyes enabled design at $1000 \mathrm{~nm}$, detectable with the usage of ZRGB camera [7], [8]. The camera revels the image hidden in the infrared spectrum parallel to the image visible in the visible spectrum. The innovative method of design and print of double IRD graphics was used in the print on small surfaces of postage stamps [9]. This media is a great example on how to place a lot information on a small limited dimension by extending the design to the infrared spectrum. In the research [10] introduced was a new technology of scanning in ultraviolet and IR (InfraRed) selections at 570, 715 and 850 nanometres. The method extended the tools of verification of authentic postage stamps as secure documents produced with new security $\mathrm{Z}$ inks. Experiments with infrared security dyes were also made on polymeric transparent materials for packaging of food and pharmaceutical products [11] for flexographic printing on polypropylene. Clear transparent labels needed to retain their natural appearance while giving necessary amount of information. The security dye setting for protection of the original products were set with $40 \%$ coverage of the carbon black dye in designed line color graphics and bar codes. In civil and army domains, twin dyes were used for design and print on camouflage uniforms [12], leather and textile clothes [13], [14], [15]. The papers show an expansion of the security area for safety uniforms, unique clothes and preservation of the artwork's authenticity. Research with twin dyes is made in the print of maps 
and plans printed in layers and with set color tones used in cartography [16], [17], [18], [19], [20]. The accuracy of the information on the maps must be secured. Research of twin dyes in security map print was presented with the separation of the $\mathrm{K}$ black dye which marked built objects, names and roads on maps. Although one color tone defines more objects on the map, made were twin dye recipes for separating the black information. Built objects and names were printed with the infrared twin dye, while roads were printed with the V (visual) twin pair. In other experiments twin dye recipes were produced for all color tones used on plans and maps. Today's technology calls for new methods of security print. Copies of scanned maps can be protected with infrared security. The digitalisation didn't stop the usage of printed maps. Examples can often be seen in tourism. The copyright of the authors original work is violated with mass scanning and copying. Applying infrared protection in

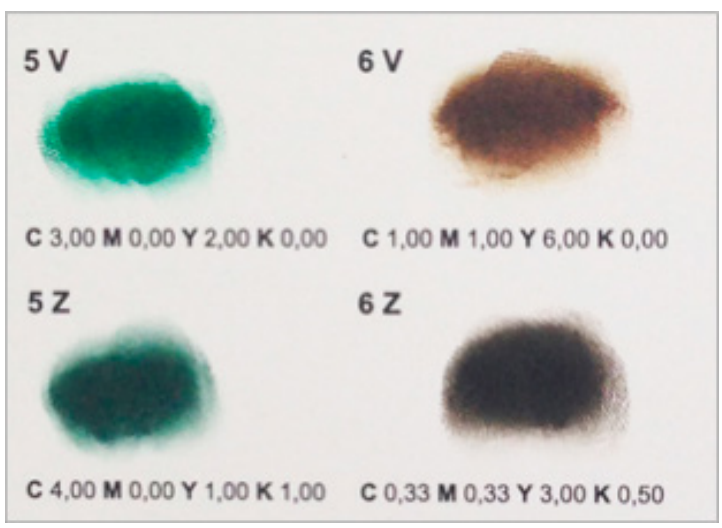

the form of the hidden authors signature provides proof of original work.

\section{Tones of monochromatic $Z$ (infrared) twin dyes}

In this paper in the experimental work, spot dyes are hand mixed. For each color tone of equal RGB and $\mathrm{L}^{*} \mathrm{a}^{*} \mathrm{~b}^{*}$ condition, different $\mathrm{Z}$ values are defined. The spot dyes are mixed with offset process colorants $\mathrm{C}, \mathrm{M}, \mathrm{Y}$ and $\mathrm{K}$. Each dye is mixed $50 \%$ with a transparent dye assuring enough lightness of color tone for the experimental work. Mixed dyes are applied in thin layers on 160 gr paper. The twin dye pair recipes were planned with dual conditions: both visible in the visual spectrum, but one hidden and one visible in the infrared. After the applied dyes have dried, spectral measurements are made for $L^{*} a^{*} b^{*}$ values of color tones. Set is a new process of mixing set color tone twin dyes for offset.

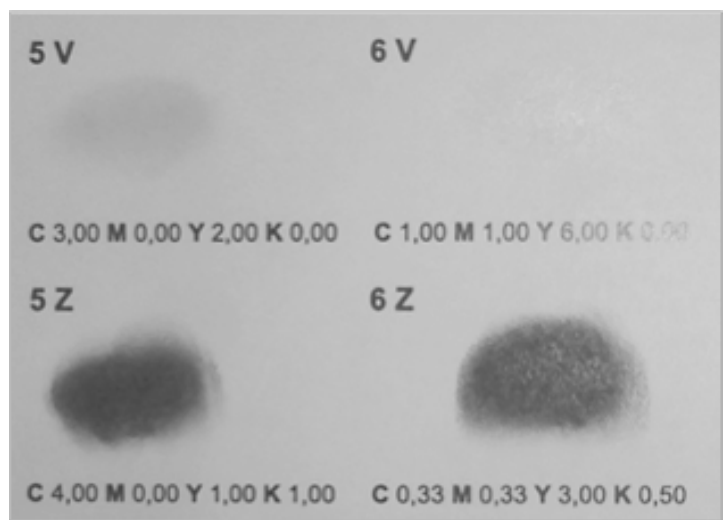

Figure 1. Dye twins for offset printing in the visual and infrared spectrums $-5 Z, V$ and $6 Z, V$
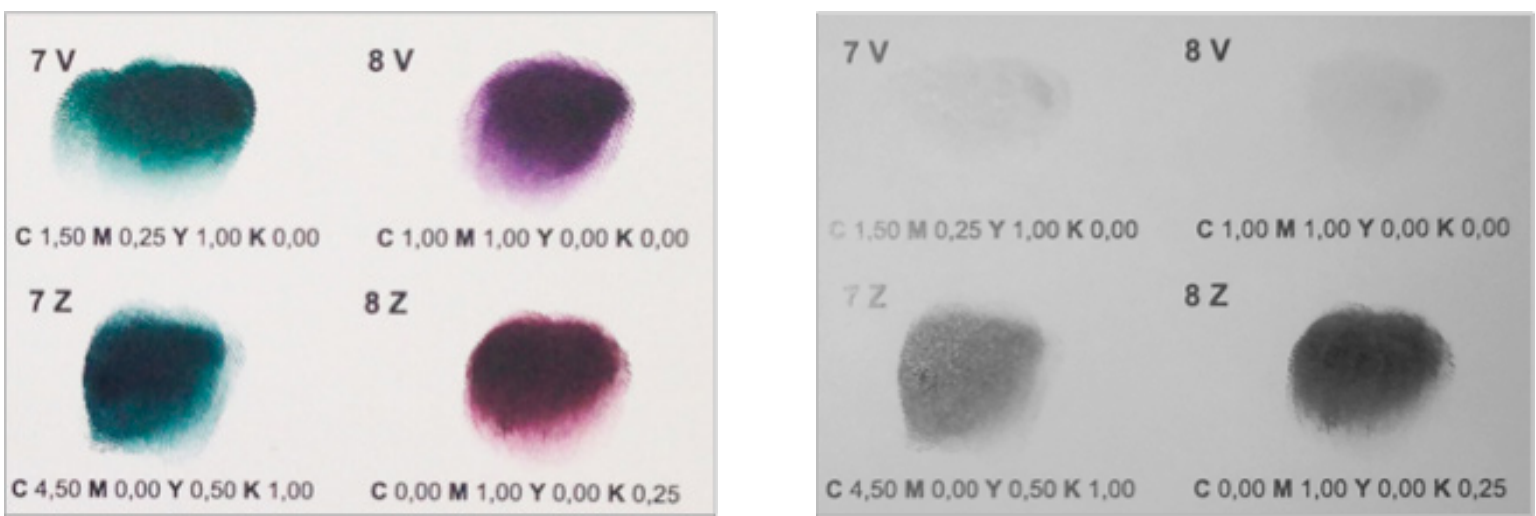

Figure 2. Dye twins for offset printing in the visual and infrared spectrums $-7 Z, V$ and $8 Z, V$ 
Tested recipes are examined by the ZRGB camera and recorded are the images of the amount of light absorption in the $\mathrm{Z}$ twin dyes. The applied dye exposed to a wavelength of $1000 \mathrm{~nm}$ demonstrates the success of the experiment in which a pair of the twin dyes does not give a response.

Table 1. $L^{*} a * b *$ values and recipes $C, M, Y, K$ dyes $5 V, Z$ $-8 \mathrm{~V}, \mathrm{Z}$

\begin{tabular}{|c|c|c|}
\hline Index & $\mathrm{L}^{*} \mathrm{a}^{*} \mathrm{~b}^{*}$ & $\mathrm{C}, \mathrm{M}, \mathrm{Y}, \mathrm{K}(\mathrm{g})$ \\
\hline $5 \mathrm{~V}$ & $40,-40,10$ & $3,0,2,0$ \\
\hline $5 Z$ & $33,-7,1$ & $4,0,1,1$ \\
\hline $6 \mathrm{~V}$ & $32,7,14$ & $1,1,6,0$ \\
\hline $6 \mathrm{Z}$ & $27,-1,5$ & $0.33,0.33,3,0.5$ \\
\hline $7 \mathrm{~V}$ & $25,-10,-1$ & $1.5,0.25,1,0$ \\
\hline $7 \mathrm{Z}$ & $27,-8,-3$ & $4.5,0,0.5,1$ \\
\hline $8 \mathrm{~V}$ & $23,8,-5$ & $1,1,0,0$ \\
\hline $8 \mathrm{Z}$ & $28,10,4$ & $0,1,0,0.25$ \\
\hline
\end{tabular}

The new mixed tones show a range in $\mathrm{Z}$ response from $0 \%$ do $64 \%$. For the $\mathrm{V}$ twin it is $0 \%$ and for the $\mathrm{Z}$ twin from $24 \%$ to $64 \%$.
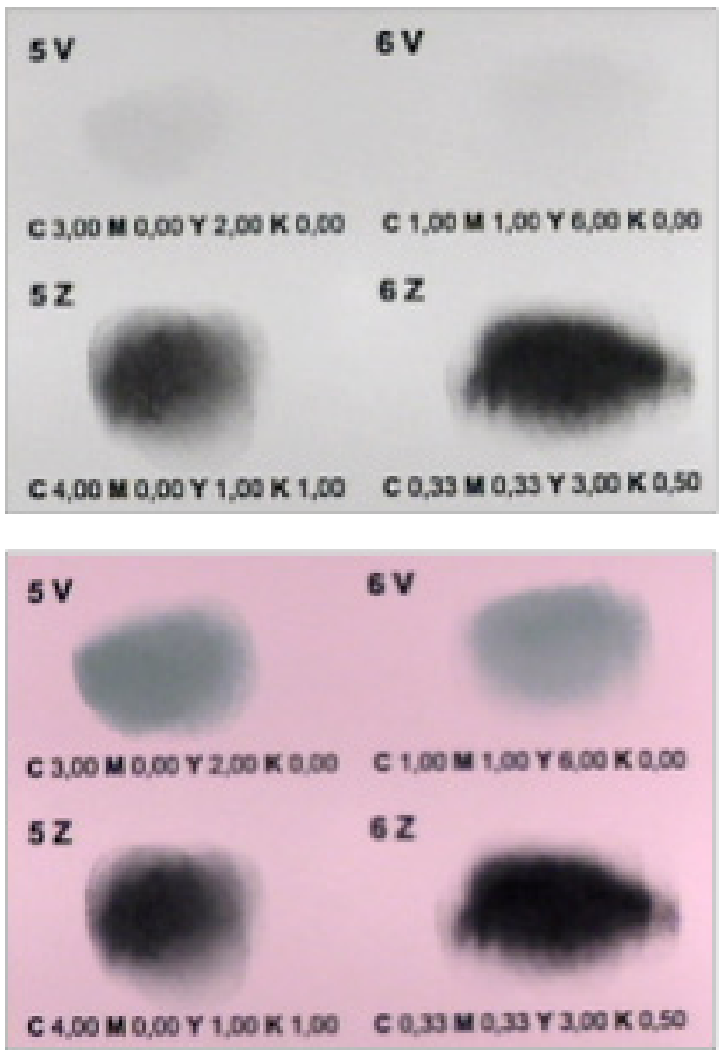

Conducted is barrier scanning of the probes. Barrier scan shows absence of certain parts of the visual spectrum. The first barrier cuts are made for the yellow component at $570 \mathrm{~nm}$. Another cut at $695 \mathrm{~nm}$ for magenta. The third barrier is cut on the border of the visual spectrum at $715 \mathrm{~nm}$ for cyan. A last scan was done at $850 \mathrm{~nm}$ in the near infrared spectrum. At $850 \mathrm{~nm}$, yellow, magenta and cyan fully reflect infrared light and the absorption takes place exclusively on the black $\mathrm{K}$ dye.

Table $2 . Z$ values and recipes $C, M, Y, K$ dyes $2-8$ in grams

\begin{tabular}{|c|c|}
\hline CMYK recipe(g) & $Z(\%)$ \\
\hline $3,0,2,0$ & 0 \\
\hline $4,0,1,1$ & 52 \\
\hline $1,1,6,0$ & 0 \\
\hline $0.33,0.33,3,0.5$ & 32 \\
\hline $1.5,0.25,1,0$ & 0 \\
\hline $4.5,0,0.5,1$ & 24 \\
\hline $1,1,0,0$ & 0 \\
\hline $0,1,0,0.25$ & 64 \\
\hline
\end{tabular}
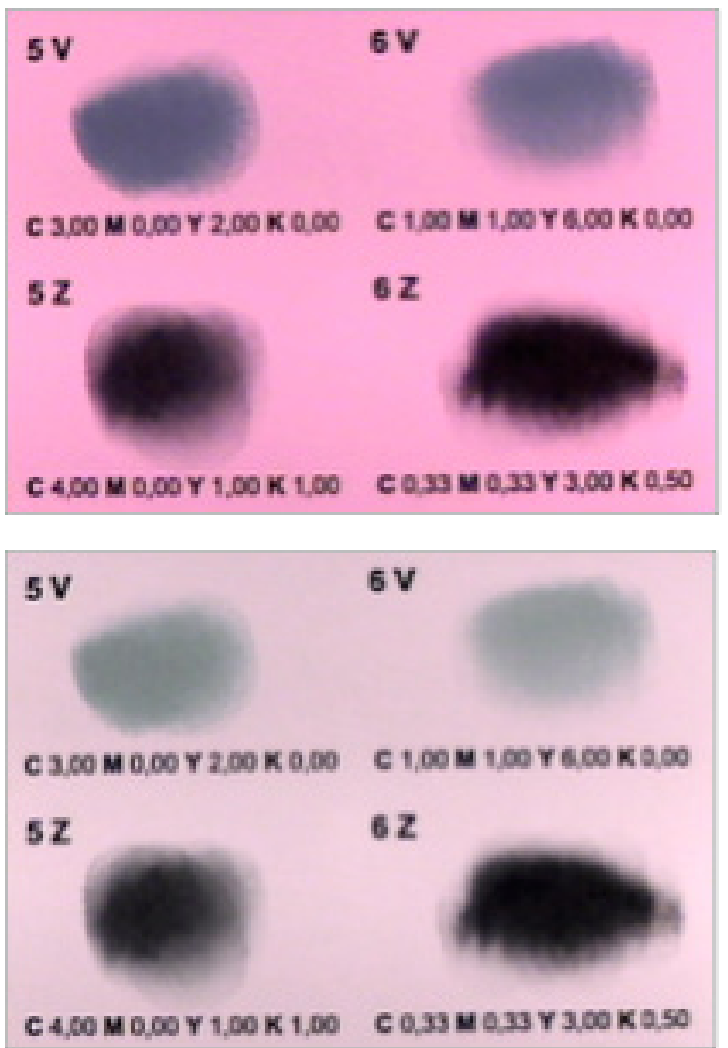

Figure 3. Display of barrier cuts at $570 \mathrm{~nm}, 695 \mathrm{~nm}, 715 \mathrm{~nm}$ and $850 \mathrm{~nm}$ of twin dyes $5 \mathrm{~V}$ and $5 \mathrm{Z}, 6 \mathrm{~V}$ and $6 \mathrm{Z}$ 


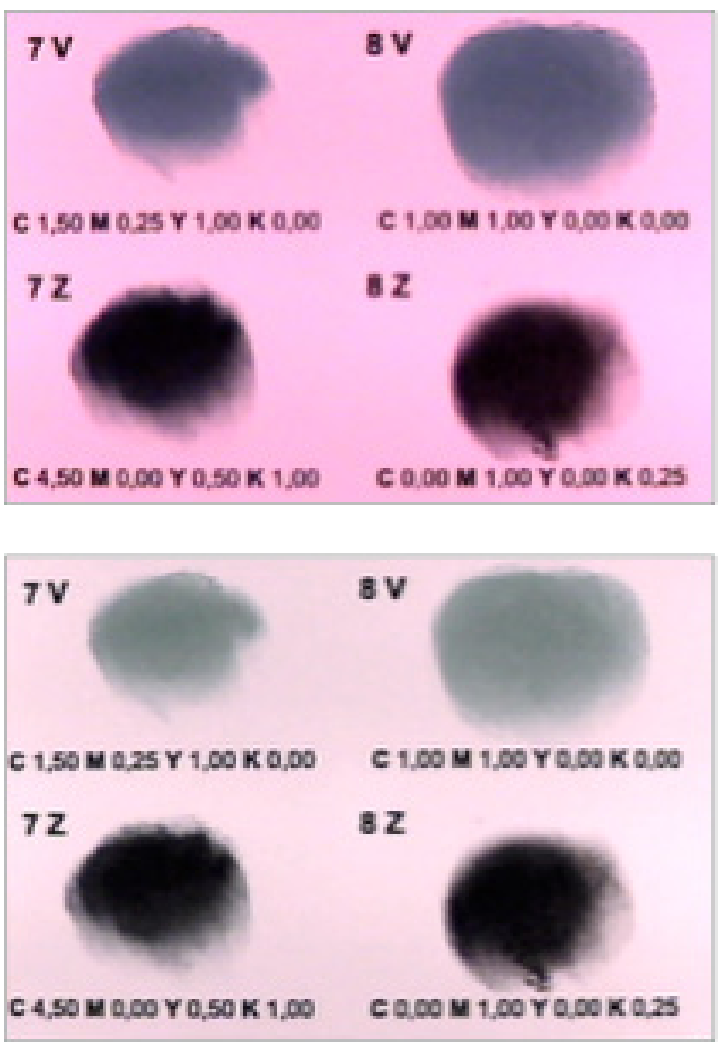

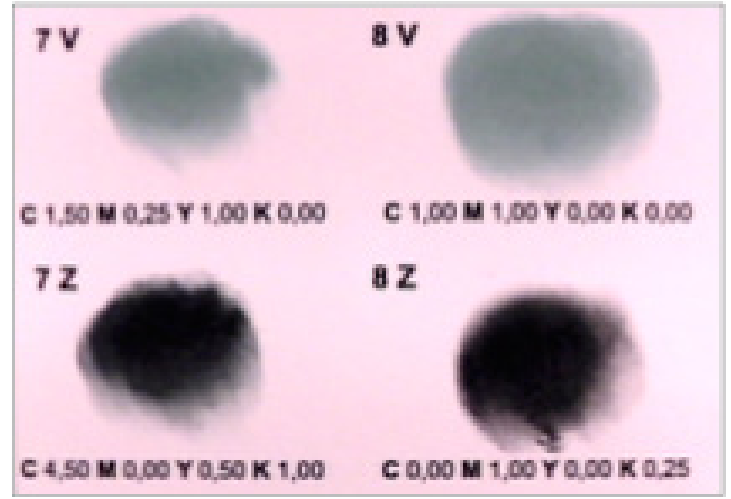

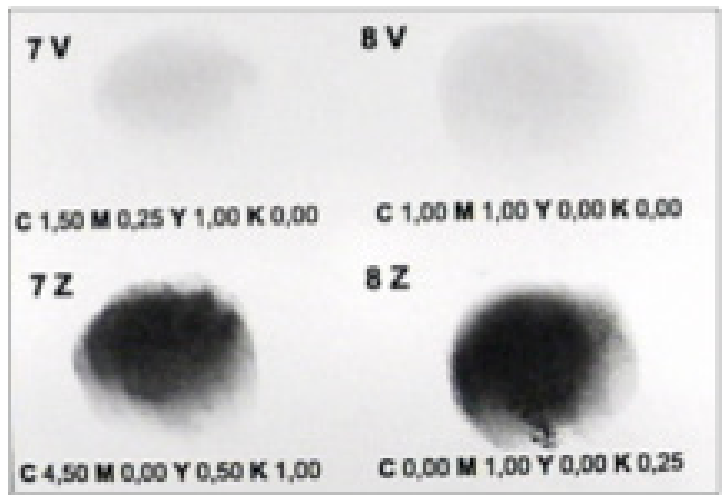

Figure 4. Display of barrier cuts at $570 \mathrm{~nm}, 695 \mathrm{~nm}, 715 \mathrm{~nm}$ and $850 \mathrm{~nm}$ of twin dyes $7 \mathrm{~V}$ and $7 \mathrm{Z}, 8 \mathrm{~V}$ and $8 \mathrm{Z}$

Imprints of 4 selected pairs of twin dyes of which only the $\mathrm{Z}$ twin dye remain visible above $1000 \mathrm{~nm}$ are shown, which proves the success of the recipe. It can be seen that the absorption of infrared light stays only on the colorant twin that contains $\mathrm{K}$. This proves that information can be hidden within pictures placed inside the black layer color or black channels in digital printing. Other dyes which do not contain the $\mathrm{K}$ component and are not included in the $\mathrm{K}$ channel are not the carrier of the information.

The importance of the twin dyes lies in the implementation of security on maps. Using the IRD security method, information on map are separated into visible and hidden elements. Original map design can be marked with the authors logo or signature, without disrupting the spatial information of a map. The protection is the mark of the author. With unauthorized copying the mark is lost. Copyright is proven by viewing the counterfeit with an infrared camera.

\section{Conclusion}

A new color gamut for offset printing which carries information in a visual and infrared spectrum was created. The principle of making twin dyes in the $\mathrm{Z}$ as a tool in shaping the hidden graphical elements was set. Twin dyes are suitable for conventional offset printing technique. Such protective dyes allow an infinite number of ways of creating graphics for the protection because with scanning or copying the infrared element is lost. The results visible with the ZRGB camera are monochrome dyes with more or less $Z$ response. The higher the percentage of the $\mathrm{K}$ dye component, the darker the grey tone is. The absorption of infrared light in the $\mathrm{Z}$ dye twin pairs is reflected in the monochromatic light and darker color grey tones. Desired levels of visibility can be set with the given recipe, show in a range of grey tones with the maximum of $64 \% \mathrm{Z}$ twin dye. The intensity of the hidden graphic is related to the dyes response in the visible spectrum. If the percentage of the $\mathrm{Z}$ grey 
tone is higher than the harder is to mix twin pairs with a tolerable value of the equalization of the experience of color tone. If the goal is to preserve original look of the graphic visible in the $\mathrm{V}$ spectrum, the grey tone is set to lighter. If the hidden graphics has priority and the $\mathrm{V}$ graphics, the grey tones are set darker, with the K component value higher. Applying infrared security within a map insures protection of copyright. Such maps cannot be copied without losing the hidden IRD graphic.

\section{References}

1. Pap K, Žiljak I, Žiljak-Vujic J. Image reproduction for near infrared spectrum and the Infraredesign theory. Journal of Imaging Science and Technology, Vol. 54. No. 1., 2010. p. 10502-1-10502-9 (9). DOI: 10.2352/J. ImagingSci.Technol.2010.54.1.010502

2. Žiljak V, Pap K, Žiljak I. CMYKIR security graphics separation in the infrared area Infrared Physics and Technology Vol.52. No.2-3, 2009. ISSN 1350-4495, Elsevier B.V. DOI: 10.1016/j.infrared.2009.01.001, p. 62-69.

3. Žiljak V, Pap K, Žiljak I. Infrared hidden CMYK graphics. The Imaging Science Journal, Vol 58., 2009. p. 20-27, ISSN: 1368-2199 Online ISSN: 1743-131X, imsmpa 045.3d DOI: 1179/136821909X12520525092882

4. Žiljak V, Pap K, Žiljak Stanimirović I, Žiljak-Vujić J. Managing dual color properties with the Z-parameter in the visual and NIR spectrum. Infrared Physics \& Technology. Vol. 55. No. 4., Elsevier B.V., 2012.

ISSN: 1350-4495, p. 326-336.

5. Agić D, Agić A, Bernašek A. Blizanci bojila za proširenje INFRA informacijske tehnologije. Polytechnic and Design, Vol. 1. No. 1., 2013. p. 27-32. DOI: https://doi.org/10.19279/TVZ.PD.2013-1-1-0

6. Agić D, Agić A, Bernašek A. Defining twin color pairs for developing comprehensive extended NIR image parameters. Politechnic \& design; Vol. 1. No. 1. , 2013., p. 27-32., ISSN: 1849-1995

7. Žiljak V, Pap K, Žiljak-Stanimirović I. Development of a prototype for ZRGB Infraredesign device. Technical Gazette, Vol. 18. No. 2., 2011., p. 153-159. URI: https://hrcak.srce.hr/69578

8. Žiljak V, Žiljak Stanimirović I, Pap K. ZRGB aparatura za dualnu detekciju, patent P20100451A, Hrvatski patentni glasnik: 2, 2012., p. 367.

9. Matas M, Rajendrakumar A, Hoić A. The role and significance of a designer in postage stamp design with infrared graphics. Tiskarstvo \& dizajn 13, 2013., p. 11-13. ISBN: 978-953-7064-20-4

10. Žiljak-Vujić J, Rudolf M, Morić B, Friščić M. Postage stamps with hidden information in security $\mathrm{Z}$ values. Technics Technologies Education Management
(TTEM). Vol. 8. No. 4. , 2013. , p. 1466-1473., ISSN: 1840-1503

11. Friščić $M$, Međugorac $O$, Tepeš L, Jurečić $D$. Invisible information on the transparent polymer food packaging with infra $\mathrm{v} / \mathrm{z}$ technology. TTEM, Technics Technologies Education Management, Vol. 8. No. 4., 2013., p. 1512 -1519. ISSN:1840-1503, e- ISSN: 1986809X

12. Žiljak Stanimirović I, Žiljak Vujić J, Stanić Loknar N. Marking of the camouflage uniform for visual and near infrared spectrum. Technics Technologies Education Management, Vol. 8. No. 3., 2013., p. 920-926. ISSN:1840-1503, e- ISSN: 1986-809X

13. Žiljak I, Pap K, Žiljak Vujić J. Infrared design on textiles as product protection. Tekstil, Vol 58. No 6., Croatian Association of Textile Engineers, 2009. ISSN: 0492-5882, p. 239-253.

14. Žiljak V, Akalović J, Žiljak-Vujić J. Upravljanje bojilima na koži u vizualnom i infracrvenom spektru. Tekstil (0492-5882) Vol. 60 No. 8., 2011., p. 355-363. ISSN: 0492-5882

15. Matas M, Žiljak Vujić J, Hoić A. Hidden information on textile design for the visual and infrared spectrum. Polythenic \& Design, Vol. 4. No. 3., 2016. DOI: 10.19279/TVZ.PD.2016-4-3-13

16. Žiljak Stanimirović I, Žiljak Vujić J, Matas M. Infrared colorants as twins for security printing of documents and securities. 45th Conference of the International Circle of Educational Institutes for Graphic Arts Technology and Management (IC), Toronto, Canada, 2013., p. 28-35.

17. Matas M, Žiljak Stanimirović I, Politis A, Pap, K. Infrared spot twin inks for the protection of cartographic print. International Circular of Graphic Education and Research, No. 8, 2015. The International Circle of Educational Institutes for Graphic Arts: Technology and Management, ISSN online: 18680879, print: $1868-0712,37-43$

18. Matas M, Žiljak V. Black twin colors on topographic maps in digital print. Acta graphica vol. 25 No. 3-4/14, 2014. p. 51-56., URI: https://hrcak.srce. $\mathrm{hr} / 138200$

19. Žiljak Vujić J, Matas M, Pogarčić M, Žiljak Stanimirović I. Topographic maps with infrared colors. 25th DAAAM International Symposium on Intelligent Manufacturing and Automation, Katalinic, Branko (ur.), Vienna : DAAAM International, Procedia Engineering Vol. 100, 2015. p. 928-935., DOI: 10.1016/j.proeng.2015.01.451

20. Pogarčić I, Agić A, Matas M. Evaluation of the colorant twins for the neutral gray spectar in Infrared Graphic procedure // Tehnički Vjesnik (Technical Gazette), Vol. 23. No. 6 , 2016. ISSN 1330-3651 (Print), ISSN 1848-6339 (Online), DOI: 10.17559/ TV- 20150303132036, p. 1659-1664.

21. Matas M. Twin dyes for security printing in infrared mapping. Doktorska disertacija, Sveučilište u Zagrebu, Grafički fakultet, 138 str., mentori Žiljak, Vilko; Sabati, Zvonimir, Zagreb, 2017., Inventurni broj 10207, URI: http://eprints.grf.unizg.hr/id/ eprint $/ 2781$ 
